PROBLEMS

OF EDUCATION

IN THE $21^{\text {st }}$ CENTURY

Vol. 79 , No. 2, 2021

192

\section{DRAWINGS TO LEARN SCIENCE: SOME REFLECTIONS}

Solange W. Locatelli

Federal University of ABC, Brazil

E-mail: solange.locatelli@ufabc.edu.br

Teacher needs to reinvent himself or herself all the time, proposing activities in the classroom that enable students to build and reconstruct knowledge. Particularly in science, this knowledge is mediated through scientific models, often inaccessible to students' understanding. For the comprehension of a chemical reaction, for example, the student is invited to imagine how the interactions between the particles would be, the atomic rearrangement, totally abstract thought and based on models, often expressed by visualizations, that need to be constantly constructed and reviewed by students. However, how to revise these abstract concepts? What strategies could be used? The answer to these questions is complex, but we would like to propose a reflection on the use of drawings, as a possibility, among so many existing ones.

We start from the premise that drawing can be used as a strategy in any age group, with the appropriate adjustments in the strategy, and not only with small children, as one might suppose. Ainsworth, Prain and Tytler (2011) defend the use of drawings for learning in science, bringing some important points, which are drawing as a way to engage students in the process, as well as a way to learn to represent, to reason and communicate in science, thus constituting an important strategy for science learning. In addition to the reasons mentioned and which we agree with, we would like to highlight the drawing as a possibility to rethink, to revise concepts. Locatelli and Davidowitz (2021) conducted a research with graduates from a Brazilian public university, in which they were proposed to study a chemical reaction between ions. The activity was carried out before the beginning of the COVID-19 pandemic, that is, in person. The students were asked to propose an explanatory model at the submicro level to explain the chemical reaction between silver ions and chloride in aqueous solution that they had just observed. After this stage, they had the task of comparing what they had done with a drawing presented by the researchers, scientifically accepted. This strategy, called the metavisual strategy, allowed students to revise their model, reconstructing some concepts that had not been previously perceived or that had been built in an inadequate way. Metavisualization, metacognition in relation to visualization (Gilbert, 2005) has been used as a strategy to review concepts that are linked to pictorial representations, as pointed out in this study. Locatelli and Davidowitz (2021) conclude that it was possible to observe the manifestation and self-regulation of the concepts demonstrated by the students, an essential and important component of metacognition that favors science learning, which shows good possibilities for the use of drawings as a strategy for learning science, in this case, related to chemistry.

Now, reflecting a little more, considering the context of the COVID-19 pandemic that is plaguing the world, we could ask whether strategies, in this perspective, could be used remotely. Yes, there are also possibilities and limits for this purpose. Locatelli (2020) conducted a research during the year 2020 (at the beginning of the pandemic isolation period), also with undergraduate students from a Brazilian public university, in which students also had to propose an explanatory model for the chemical reaction between ions. However, the context and methodology were different, since students developed the activity entirely by remote means, using various technological resources: Facebook, google forms, among others. Although, it was also observed that the metavisual activity with the use of drawings proved to have good possibilities of revising concepts, these can occur in a partial way, since the students 
found some difficulties in chemistry that could be overcome (self-regulated) and others did not, evidencing the importance of teacher mediation during the activity, as a possible factor that influenced the development of the activity, in addition to the context itself, a very peculiar social isolation. It is important to note that this showed both possibilities and limitations, and the concepts can and should be taken up using a synchronous class (via meet) or even face-toface classes return.

In the two studies described, it was possible to observe the relevant points pointed out by Ainsworth, Prain and Tytler (2011) about the importance of using drawings. The self-regulation of concepts (metacognitive aspect) was also present in both research studies, but the most evident difference was the mediation of the teacher that could be done on the same day, in the face-to-face case, differently from mediation through remote means, which was performed some time later in a synchronous class. Actually, this was not a problem (since it was solved later), but a limitation and which helped to strongly highlight the importance of teacher mediation in the students' learning process. In addition, as already mentioned, the different context in which the research took place (before and during the pandemic) certainly influenced the performance of students in some way, which we intend to discuss at another time.

Even in the face of the challenges described, drawing can be an excellent opportunity to learn science, enabling the review of scientific concepts.

\section{References}

Ainsworth, S., Prain, V., \& Tytler, R. (2011). Drawing to learn in science. Science, 333(6046), 10961097. https://doi.org/10.1126/science. 1204153

Gilbert, J. K. (2005). Visualization: A metacognitive skill in science and science education. In J. K. Gilbert (Eds.), Visualization in science education (pp. 9-27). Springer.

Locatelli, S. W., \& Davidowitz, B. (2021). Using metavisualization to revise an explanatory model regarding a chemical reaction between ions. Chemistry Education Research and Practice, 1, 1-14. https://doi.org/10.1039/D0RP00339E

Locatelli, S. W. (2020). Entender una reacción química entre iones a través de tecnologías digitales - límites y posibilidades [Understanding a chemical reaction between ions through digital technologies - limits and possibilities]. Paradigma - Revista del centro de Investigaciones Educacionales Paradigma, 41(2), 172-189. https://doi.org/10.37618/PARADIGMA.1011-2251.0.p172-189.id863

Received: March 14, 2021

Accepted: April 02, 2021

Cite as: Locatelli, S. W. (2021). Drawings to learn science: Some reflections. Problems of Education in the $21^{\text {st }}$ Century, 79(2), 192-193. https://doi.org/10.33225/pec/21.79.192

Solange W. Locatelli
$\mathrm{PhD}$, Department of Chemistry, Federal University of $\mathrm{ABC}, \mathrm{Av}$. dos

Estados, 5001 - Bangú, Santo André - SP, 09210-580, Brazil.

E-mail: solange.locatelliufabc.edu.br

ORCID: https://orcid.org/0000-0002-7639-6772
PROBLEMS

OF EDUCATION

IN THE $21^{\text {st }}$ CENTURY

Vol. 79, No. 2, 2021 